[19] ポリブタジェンーメタクリル酸メチルグラフトポリマーの分別 (1967 年 8 月 5 日受理)

劍 実夫* ·福元次夫* . 小川宏蔵*

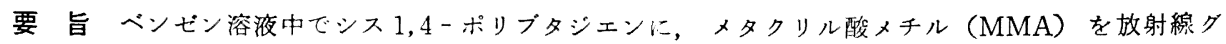
ラフト重合し, 生成した粗ボリマーをベンゼンーメタノール系で分別沈䝘した。個々のフラクションに ついて, MMA 含量と数平均分子量を測定し, また，オゾン分解によって枝分子のポリメタクリル酸メ チル (PMMA) を取り出し, その粘度平均分子量を求めた。その結果, この系でグラフトポリマーは 主としてその化学組成, すなわち MMA 含量の多少によって分別されるものであり, また枝の数はフ ラクションによってほとんど変化がないことが推定された。
\end{abstract}

\section{1. 緒言}

コムのグラフトポリマーの構造, 特に枝の数と分子量 については,これまでいくつかの報告がある。Angier ら゙は天然ゴムに MMA をグラフト重合したものにつ いて, Sebban-Danon"1 はポリイソブナレンースチレン 系について, 原田ら ${ }^{31}$ はポリブタジェンにスチレンをア ニオングラフト重合したものについて，それぞれ報告を 出している。

著者らは枝の数と分子量について，さらに詳しい知見 を得るために，ベンゼン溶液中でポリブタジェンにメタ クリ酸メチル（MMA）を放射線グラフト重合し，生成 した粗ポリマーを分別沈殿した。そしてグラフトポリマ 一と考えられる領域の個々のフラクションについて, NMR により MMA 含量を, 浸透圧法により数平均分 子量 $\left(\bar{M}_{n}\right)$ を決定し, さらにオゾン分解により枝分子 であるポリメタクリル酸メチル（PMMA）を取り出し て，その粘度平均分子量を求めた。

\section{2. 実 験}

\section{1 粗ポリマーの調製}

窒素気流中で, ベンゼンーメタノール，ベンゼンーア セトン采を用いて再沈殿により精製したシス含量 $97 \%$ の 1,4 ポリブタジェン（J.S.R., BR-01：以下 $\mathrm{PB}$ と 略する）をベンビンに溶かし，MMA モノマーを加え, 通常の方法により脱気溶封して照射溶液とした。溶液中 の PB， MMA の濃度はそれぞれ $1 \mathrm{~g} / \mathrm{d} l, 18.5 \mathrm{~g} / \mathrm{d} l$ であり, PB のブタジェン単位と MMA のモル比が 1: 10 である。

適切なサンプリンクを行ならため，まず Co-60の 線の線量に対する重量增加をチェックしたところ, Fig. 1 に示す結果を得た。横軸は照射線量, 縦軸左側は照射 によるポリマーの重量増加を示す。たとえば，100\% 增 加とは生成した粗ポリマーの量がもとの PB の量の 2

\footnotetext{
* 大阪府立放射線中央研究所（大阪府堺市新家町）
}

倍となったことを示しでいる。縦軸右側は MMA モノ マーの重合率を示す。この線量の範囲では直線関係ぶ得 られている。な扣線量率は $0.5 \times 10^{5} \mathrm{r} / \mathrm{h}$ である。以後 の実験に適当と思われる線量として, 約 2 倍の增量が得 られる $1.5 \times 10^{5} \mathrm{r}$ 用いて，粗ポリマーを調製した。

\section{2 粗ポリマーの分別}

粗ポリマーの $1 \%$ ベンゼン溶液を調整し，沈殿剤とし て $0.01 \%$ の塩化カルシウムを含んだメタノ一ルを用 (、4), 窒素気流中で分別沈殿をおこなった。Fig. 2 に その結果を示す。横軸はメタノールとペンゼンの容積比 を示し, 縦軸は積算重量である。メタノールとペンゼン の比が 2 付近までの沈殿物はいずれもコロイド状のゾル を形成しており，20000Gで20 分間遠心分離しなければ ならなかった5!。なおこの遠心分離の過程で操作上のミ スのため第 1 フラクション（図中の左端の白丸）をかな り失った。このため全回収率は $85.28 \%$ となった。 各フラクションの精製はフラクションを再びベンゼン

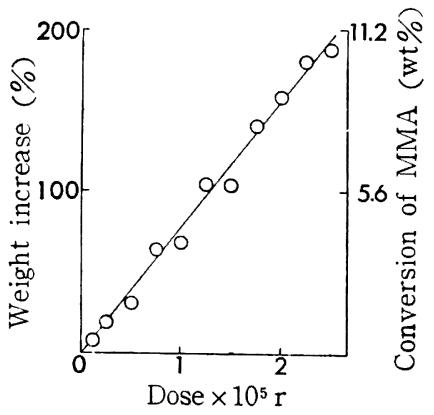

Dose rate $0.5 \times 10^{5} \mathrm{r} / \mathrm{hr}$

Condition: in vaccum, at room temp. Composition of irradiated solution

$$
\left\{\begin{array}{l}
\text { BR-01 } 1.0 \mathrm{~g} / \mathrm{d} l, \\
\text { MMA } 18.5 \mathrm{~g} / \mathrm{d} l
\end{array}\right.
$$

Fig. 1. Dose dependence for the polymerizatio of methyl methacrylate in the presence of polybutadiene. 
昛溶かし、それぞれが生成したと同じ割合のメタノール を加えて再沈殿させることにより行なった。

\section{3 フラクションの MMA 合量}

個々のフラクションの MMA 含量は NMR で定量 した。フラクションの約 $5 \%$ クロロホルム溶液を作製 し，そこへ内部標準として適量の $1 ， 1 ， 2 ， 2$-テトラ クロロエタン（TCE）を加えて測定溶液とした。その

一例として第 5 フラクションのスペクトルを Fig. 3 に 示す。図で $\tau=6.39$ のピークは MMA の $-\mathrm{O}-\mathrm{CH}_{3}$ 基の存在を, $\tau=4.05$ のピークは TCE の存在を示し ている。残りの二つのピークはいずれもPBに帰因す るものである。上部の曲線はこのスペクトルの積分曲線 であり，それぞれのピークの面積を示している。MMA

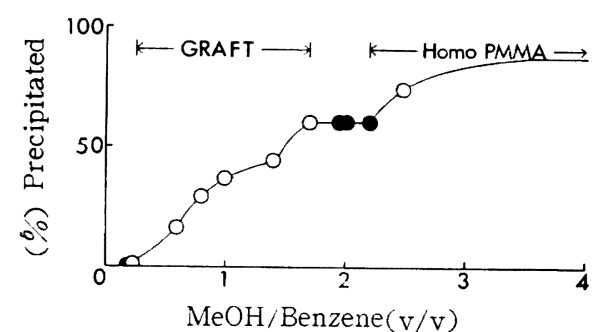

Fig. 2. Fraction of the gross polymer.

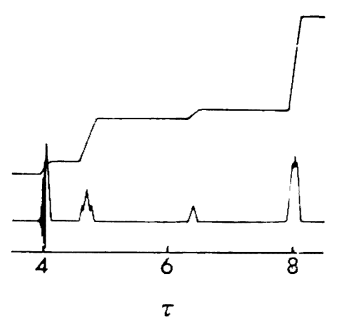

Fig. 3. NMR spectrum of fraction No. 5 .
の - O- $\mathrm{CH}_{3}$ 基が示すピークと $\mathrm{TCE}$ のピークの面䅡比 から各フラクション中の MMA 含量を定量した。

\section{4 浸透圧測定}

各フラクションの $\bar{M}_{n}$ を高速浸透圧計で測定した。 溶媒はベンゼン, 膜は Schleicher and Schull type の メンブラン（ゲルセロハン）を用いて $25^{\circ} \mathrm{Cで}$ 測定し た。

\section{5 オソンン分解}

フラクションの $1 \%$ クロロホルム溶液を作成し, フラ クション中に含まれている MMA の約10倍量（重虽） の di- $n$-butyl sulfide を加えて試料溶液をつくり，オデ ンを $\mathrm{PB}$ の二重結合を全部切断するに要する量より $5 \%$

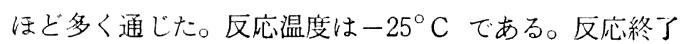
後, 適量の氷を加えて徐々に加温してオゾナイドを分解 した。残留物はベンゼンーメタノール系で 2 回再沈精㓟 し、それが PMMA だけであることを赤外吸収スぺク トルで確認した。

なお，予備試験として，PB と PMMA のブレンド物 について同様の実験を行なった。PMMA の粘度 $[\eta]$ は オゾン処理により約 $5 \%$ 低下し Barnard の結果 ${ }^{6 !}$ と一 致している。

\section{6 粘度測定}

オゾン分解により取り出した忮分子の分子量を求める ため浸透压測定を試みたが唚透圧計の圧の読みが一定値 におさまらないで，時間の経過とともに漸次減少してい った。これは枝分子中の低分子量のものが償を透過した 結果であり, 後述の粘度平均分子量と考光合わせると, 枝分子にかなりの分子量分布があるためと思わ机る。そ れゆえ, 極限粘度を測定し, Baxendale ら》が PMMA の分別試料について求めた粘度 - 分子量関係式

$$
\left([\eta]=0.94 \times 10^{-4} M^{0.76}\right)
$$

から，こ机ら枝分子の粘度平均分子量 $\left(\overline{\mathrm{M}}_{v}\right)$ を算出し

Table 1. Characterization of each Iraction.

\begin{tabular}{|c|c|c|c|c|c|c|c|c|c|}
\hline \multirow[b]{2}{*}{ No. } & \multicolumn{6}{|c|}{ Graft Polymer } & \multicolumn{2}{|c|}{ Side Chain } & \multirow[b]{2}{*}{$\frac{(\mathrm{M})_{s}}{\left(\bar{M}_{v}\right)_{s}}$} \\
\hline & $\begin{array}{c}\mathrm{MeOH} \\
\mathrm{C}_{6} \mathrm{H}_{6} \\
\end{array}$ & $\begin{array}{c}\text { wt } \\
\text { fracion }(\%)\end{array}$ & $\begin{array}{c}\text { MMA } \\
\text { content }(\%)\end{array}$ & $\begin{array}{c}\bar{M}_{n} \\
\left(\times 10^{-5}\right) \\
\end{array}$ & $\begin{array}{c}(\mathrm{M})_{t} \\
\left(\times 10^{-5}\right)\end{array}$ & $\begin{array}{c}(\mathrm{M})_{s} \\
\left(\times 10^{-5}\right)\end{array}$ & $\begin{array}{c}{[\eta]} \\
(\mathrm{d} l / \mathrm{g})\end{array}$ & $\begin{array}{l}\left(\overline{\mathrm{M}}_{v}\right)_{s} \\
\left(\times 10^{-5}\right)\end{array}$ & \\
\hline 1 & 0.22 & 0.73 & .......... & ...... & ...... & $\ldots \ldots$ & $\ldots \ldots$ & $\ldots \ldots$ & $\ldots \ldots$ \\
\hline 2 & 0.60 & 15.63 & 12.41 & 1. 49 & 1.31 & 0.18 & 0.350 & 0.50 & 0.36 \\
\hline 3 & 0.80 & 12.27 & 13.11 & 1. 49 & 1.29 & 0.20 & 0.391 & 0.58 & 0.34 \\
\hline 4 & 1.00 & 8.16 & 16.21 & 1.57 & 1.32 & 0.25 & 0.418 & 0.63 & 0.40 \\
\hline 5 & 1. 40 & 7.16 & 20.47 & 1.58 & 1. 26 & 0.32 & C. 450 & 0.70 & 0.46 \\
\hline 6 & 1.70 & 16.22 & 30.47 & 2.10 & 1. 46 & 0.64 & 0.735 & 1. 32 & 0.48 \\
\hline 7 & 2.48 & 10.30 & $100 . \cdots$ & $\ldots \ldots$ & $\ldots \ldots$ & $\ldots \ldots$ & $\ldots \ldots$ & $\ldots \ldots$ & $\ldots \ldots$ \\
\hline 8 & $\ldots \ldots$ & 14.81 & $100 . \cdots$ & $\ldots \ldots$ & $\ldots \ldots$ & $\ldots \ldots$ & $\ldots \ldots$ & $\ldots \ldots$ & $\ldots \ldots$ \\
\hline
\end{tabular}

$(\mathrm{M})_{t}$ : Molecular weight of backbone chain part

$\left(\mathrm{M}_{\mathbf{s}}\right.$ : Molecular weight of side chain part 
た。粘度計はウペローテ希釈型粘度計, 溶媒はベンゼン, 測定温度は $25^{\circ} \mathrm{C}$ である。

\section{3. 結果と考察}

Fig. 2からわかるようにグラフトポリマー領域とフリ - PMMA 領域はきわめて明確に分かれている (Table 1 の左から第 4 欄の MMA 含量はフラクション番号 7, 8 が 100\% を示している)。また予備試䤅として PB と PMMA のブレンドについて分別沈股を行なったとこ ろ,メタノールとペンビンの比が約 0.25 の所で PB が 全部沈㔀することを確認した。Fig. 2 においてメタノー ルとベンゼンの比が $0.25 \sim 1.75$ の間の沈殿物はほぼグ ラフト物であると考光られる。

Table 1 は以上の実験結果を総括したものである。 左から第 1 欄は分別沈殿によって得られた各フラクショ ンの番号、第 2 欄はそれぞれのフラクションが生成した ときのメタノールとベンゼンの比を, 次の列は重量分率 を示している。な书第8フラクションは溶媒をすべて票 発させて残留物をとり出したものである。

第 4 列は NMR で求めた MMA 含量を重量\%で示し ている。メタノールの割合が大きくなるにともないフラ クション中の MMA 含量が增加している。なお, フラ クション1は操作上のミスのため収量が少なくなり, 以 後の実験はできなかった。表からわかるよらに, フラク ション 2 〜はグラフト重合物であり, フラクション7,8 はフリーPMMA である。そこでこ机以後の実験はフ ラクション2〜6のものについて行なった。

一般にグラフト重合物の分別沈殿はポリマーの分子 量, 化学組成、枝の数と長さの三つの性質に依存すると いわ机ている。本実騃の場合, この三つの内, どれが最 も大きく影響しているかを考えると，この欄は化学組成 に大きく依存していることを示している。

第 5 闌は個々のフラクションの $\bar{M}_{n}$ を示している。 メタノール添加量の增加にともない分子量が大きくなっ ている。第 6,7 概はフラクションの幹部分の分子量と 枝部分の分子量である。これらの值はフラクションの $\bar{M}_{n}$ と MMA 含量から算出した。幹部分, 寸なわち, $\mathrm{PB}$ 部分の分子量はフラクションによる相迲はほとんど なく、枝部分の分子量はメタノール增加に伴い大きくな っている。

以上メタノール添加量の增加に伴い,グラフトポリマ 一中の枝部分の分子量（すなわち MMA 含量）は增加
するのに反し, 幹部分の分子量は変化しないことから, 本実験での分別沈殿注注注化学組成. すなわち, クラフ トポリマー中に含まれている MMA の含量に依存し, 分子量には依存しないと考兄られる。

第 8,9 欄はオゾン分解により取り出した枝分子の極 限粘度と，それを Baxendale らの式にあてはめて得ら れた粘度平均分子量を示している。メタ, 一ル增加にと もない枝の $\bar{M}_{v}$ は增加している。

最後の欄はフラクションの枝部分の分子量を, 実際に とり出した枝分子の $\bar{M}_{v}$ で割った値である。枝分子の分 子量分布の問題もあって, この值をそのまま枝の数にあ てはめることはできないが，いずれにしても幹ポリマー あたりの枝の数に関倸つけられる。

この欄を見ればわかるよらに，この值はフラクション によって大きな変化はない。このことから，幹分子あた りの枝の数はフラクションによってほとんど変化してい ないと推定される。

な㧍，今後，大量のグラフトポリマーを作製して，才 ゾン分解により枝部分のみをとり出しその分子量分布を 決定して, 幹ポリマーあたりの枝の数と分子量を決めて ゆく予定である。

付記：本研究の実施にあたり, BR-01 を提供し ていただいた東洋ゴム工業株式会社,ならびに高速浸 透王計を使用させていただいた大阪工業技術試跧所の 河合和三郎博士に深謝します。本稿は第 16 回高分子 学会年次大会（1967 年 5 月，東京大学）で講渞した ものである。

\section{文献}

1) D.J. Angier, D.T. Turner: J. Polymer Sci., 28, 265 (1958)

2) J. Sebban-Danon: J. Chim. Phys., 58, 246 (1961)

3）原田 洋, 椎名 教, 箕浦有二：工化, 69,2320 (1966)

4) F.M. Merrett: Trans. Faraday. Soc., 50, 759 (1954)

5) D.J. Angier, W.F. Watson: J. Polymer Sci., 25, 1 (1957)

6) D. Barnard: J. Polymer Sci., 22, 213 (1956)

7) Baxendale, J.H., S. Bywater, M.G. Evans: J. Polymer Sci., 1, 237 (1946) 


\title{
Fractionation of Polybutadiene-Methyl Methacrylate Graft-polymer
}

\author{
by Jitsuo Tsurugi*, Tsugio Fukumoto* and Kozo Ogawa*
}

\begin{abstract}
Methyl methacrylate (MMA) was grafted to cis-1, 4-polybutadiene by $\gamma$-irradiation in benzene solution. Graft polymer was separated from homopolymers by fractional precipitation with benzene-methanol. MMA content and number average molecular weight of each fraction were determined. Poly (methyl methacrylate) chain in graft polymer was separated from the backbone chain by ozonolysis of the latter, and viscosity average molecular weight of the former was determined.

In the present fractional precipitation, chemical component, i.e., MMA content of graft polymer was found to predominate over other factors. Number of side chain per backbone chain may not be so different from each other in all fractions of graft polymer.
\end{abstract}

* Department of Chemistry, Radiation Center of Osaka Prefecture (Shinke-cho, Sakai, Osaka) 